\title{
28 Research Soure \\ Conditional Survival Probability of Non-Small Cell Lung Cancers, Based on The SEER Database
}

\section{Shixu Fang}

The Affiliated Hospital of Zunyi Medical University

\section{Kui Zhai}

The Affiliated Hospital of Zunyi Medical University

\section{Xixian Ke}

The Affiliated Hospital of Zunyi Medical University

\section{Hao Han}

The Affiliated Hospital of Zunyi Medical University

Hongling Lu

Zunyi medical university

\section{Gang Xu ( $\nabla$ xglhl333@163.com )}

The Affiliated Hospital of Zunyi Medical University

\section{Research Article}

Keywords: Non-small cell lung cancer, Non-metastasis, postoperative, conditional survival probability, SEER database

Posted Date: February 4th, 2021

DOI: https://doi.org/10.21203/rs.3.rs-138915/v1

License: (c) (i) This work is licensed under a Creative Commons Attribution 4.0 International License. Read Full License 


\section{Abstract}

Background: This study aims to explore the dynamic survival probability of lung cancers after resection based on those had survived several years, provide more precise monitoring and treatment information for non-metastatic non-small cell lung cancer (NSCLC) patients.

Materials and Methods: In the Surveillance, Epidemiology, and End Results (SEER) database (20002016), 95531 eligible non-metastatic NSCLC patients after surgery were enrolled, TNM stage were reclassified, the methods of condition survival probability (CS) and actuarial overall survival (OS) were used to explore the relationship between clinicopathological characteristics and cancer prognosis.

Results: The 1-, 3-, 5- and 10-year OS of included patients were 83.6\% (95\% Cl: 83\%-84\%), 62.9\% (95\%Cl: $62.6 \%-63.1 \%$ ), 50.8\% (95\% Cl: 50.6\%-51.0\%) and 33.1\% (95\% Cl: 32.7\%-33.6\%) respectively. For those already survived 1, 2, 3, 4 and 5 years after diagnosis, the probability for surviving an additional 3 years were $67 \%, 71 \%, 73 \%, 75 \%$ and $77 \%$ respectively. Enrolled population were reclassified into 9 cohorts including T1aNO, T1bN0, T1cN0, T2aNO, T2bN0, T3N0, T4N0, T1-4N1, T1-4N2 according to 8th TNM staging. According to the conditional survival probability, patients with unfavorable tumor stage diagnosed initially at surgery had the significant improvement in CS over time. Analysis based on other clinical features demonstrated similar conclusion that the poorer the initial diagnosis, the more significant the benefit of conditional survival over time.

Conclusion: The worse the patient's prognosis, the more significant the benefit of time-dependent conditional survival probability, long-lived cancer patients may have a better cancer prognosis.

\section{Introduction}

Survival estimates for cancer patients was traditionally based on TNM stage at the time of diagnosis or after diagnosis or treatment [1], which answered prognostic questions that many cancer patients care about. This result makes the 5-year survival rate of cancer patients a fixed value, and could be understood as "static survival estimate" [2]. However, for those who have survived for several years after diagnosis, the survival probability established at the time of diagnosis may not be applicable, because the overall survival rate of patients includes those who died within the first few years, as well as those who have passed through the first few years and "stand out" from them. For those patients pass through the first few years, the doubt troubling them may be "If I have already lived $x$ years after diagnosis, what is the probability that I survive for another $y$ years".

In the past few years, the occurrence of conditional survival (CS) probability has given this question an exact answer [3], the CS refers to the probability of surviving for another $n$ years if the patient with chronic disease has been alive for $m$ years after diagnosis or treatment, the concept was derived from the conditional probability in biostatistics [4-6]. It can provide a dynamic and more precise survival rate for cancer patients [7]. It is well known that the prognosis of cancer patients who survived in the first few years will be better, because the impact of death risk factors on the prognosis of patients will gradually 
weaken over time [8-10], and as we all known, for those patients who have pass through the first few years after radiotherapy or chemotherapy, the adverse effects of radiotherapy and chemotherapy on the body gradually weaken. Conditional survival means that, on average, the prognosis of long-term cancer survivors are better than these newly diagnosed patients [11-13]. This study aims to explore the postoperative conditional survival of patients with non-distant metastatic non-small cell lung cancer, providing more powerful information for doctors to formulate treatment plans and monitoring plans, giving patients and doctors a new understanding of cancer prognosis.

\section{Patients And Methods}

\subsection{Data Source}

The patients of this study was selected from the National Cancer Institute database (The Surveillance, Epidemiology, and End Results, SEER) [14]. The raw data in this investigation was downloaded from the SEER web site (https://seer.cancer.gov/data/) via SEER*Stat in client-server mode after we submitted a request for access and signed the SEER research data agreement.

\subsection{Study Population}

In this study, non-metastatic NSCLC from 18 registration centers in the SEER database were obtained. Since the SEER database is a public database, analysis of lung cancer patients does not require informed consent and institutional review. The clinical pathological characteristics of the patients were screened, the inclusion criteria are: 1) 15 years old or older patients diagnosed with lung cancer between 2000 and 2016 years; 2) with definite pathological diagnosis of NSCLC; 3) Single primary tumor; 4) Complete followup data (patients who died within 1 month after diagnosis were excluded, lack of specific follow-up time was also excluded); 5) Complete clinical pathological characteristics (such as age, tumor size, whether surgery, TNM stage). Exclusion criteria include: 1) metastatic lung cancer; 2) lack of T and N stages; 3 ) Tumor size is not available, histological and grade information is unclear; 4) diagnosis based on autopsy or death certificate only; 5) Died within one month of diagnosis or lack of follow-up data. The patient's TNM staging was reclassified based on the eighth edition of the American Joint Committee on Cancer (AJCC) staging standard according to the tumor size. Detail in Figure 1.

\subsection{Statistical Analyses}

The analysis of this study is based on two steps. First, TNM stage was reclassified based on tumor diameter according to the $8^{\text {th }}$ version of the American Joint Committee on Cancer (AJCC) staging (T1aN0, T1bN0, T1cN0, T2aN0, T2bN0, T3N0, T4N0, T1-4N1, and T1-4N2). Clinicopathological characteristics were also stratified, such as surgical situations, positive lymph nodes, tumor grade, tumor size and patient age. (Details in Table 1). Subsequently, Kaplan-Meier method was used to analyze actuarial survival rate of cancers, such as 5-year survival rate or 10-year survival rate. Most of the missing values in this article were eliminated. 
Another statistical method involved in this study is the conditional survival probability. To illustrate how we obtain conditional survival estimates from the cumulative survival estimates, suppose we are interested in the population's 5-year lung cancer survival probability conditioned on already having survived 5 years. The estimate is obtained by dividing the cumulative survival at 10 years by the cumulative survival at 5 years. The 1-year lung-cancer survival estimates conditioned on already having survived 5 years after diagnosis are derived by dividing the

cumulative survival estimates at 6 years by the cumulative survival estimates at 5 years. Subtracting this survival probability from 1 gives the probability of dying in the year conditioned on having already survived 5 years. CS was adopted to estimate the survival probability, the mathematical definition of CS could be expressed as: CS $(n \mid m)=\mathrm{S}(n) / \mathrm{S}(m),(m<n)$, where CS $(n \mid m)$ is the probability of survival $n$ years assuming that patient have already survived for $m$ years after diagnosis. In this study, we estimated the additional 5-year conditional survival probability of patients given that they have already survived $x$ years using the mathematical formula $\triangle \operatorname{CS}(x+5 \otimes x)=\operatorname{OS}(x+5) / \operatorname{OS}(x)$. Finally, the differences between the actuarial OS and the CS of the population were compared and analyzed. All statistical methods were implemented by Graphpad prism version 8.0.2 and R language 3.6.3 version, all statistical tests are twosided, $P$ value $<0.05$ is considered statistically significant.

\section{Results}

\section{Overall Population}

From 2000 to 2016 years, 95,531 postoperative patients with non-metastatic NSCLC were included (For ease of comparison, 4346 non-surgical patients were also included in this study). The average age of the patients was 62 years old. Almost half of the patients were male $(46863,49 \%)$. Stages distribution (restaged according to the tumor size) were as follows: 4499 cases (9.42\%) with pT1aN0, 21138 cases (22.13\%) with pT1bN0, 17254 cases (18.06\%) pT1cN0, 9587 cases (10\%) with pT2aN0, 5100 cases (5.33\%) with pT2bN0, 4790 cases (5.01\%) with pT3N0, 4409 cases $(4.61 \%)$ with pT4N0, 12021 cases (12.58\%) with pT1-4N1, 11517 cases (12.05\%) with pT1-4N2. The average of tumor size is $3.32 \mathrm{~cm}$, Grade I-IV and unknown were accounts for $13.5 \%, 36 \%, 33 \%, 2.5 \%$ and $15 \%$ respectively, the primary tumor site was divided into the upper lobe, middle lobe, lower lobe and other locations, positive regional lymph nodes accounted for 36058 (37.8\%). The surgical intervention situations were divided into non-operation, local ablation or cauterization, sublobar resection, lobectomy, pneumonectomy and other surgical methods. 22,530 patients $(23.5 \%)$ received chemotherapy and 12,631 patients $(13.1 \%)$ received radiotherapy (Table 1).

At the last follow-up, the median follow-up time was 62 months, the number of deaths or events was 51,175. 1-year, 3-year and 5-year OS were 83.6\% (95\%Cl: 83\%-84\%), 62.9\% (95\% Cl: 62.6\%-63.1\%) and $50.8 \%(95 \% \mathrm{Cl}: 50.6 \%-51.0 \%)$ respectively. Figure $2(\mathrm{~A})$ shows the rapid decline of overall survival rate in the first three years. Although the overall survival of lung cancers shows unsatisfactory, for those living several years after diagnosis, the mortality rate is gradually decreasing Figure $\mathbf{2}(\mathbf{B})$ and the probability 
rates for surviving an additional 5 years were steadily increased (Figure 2(C-D) and Table 2). Figure 3 shows the decrease of the actuarial survival rates over time and the increases of estimated CS(8) for 1-5 years in total patients, which demonstrated that as the survival time of cancers increases, the gap between overall survival rate and conditional survival rate becomes more significant.

\section{$8^{\text {th }} \mathrm{T}$ and $\mathrm{N}$ stage}

Enrolled population were reclassified into 9 groups including T1aNO, T1bNO, T1cNO, T2aN0, T2bNO, T3NO, T4N0, T1-4N1, T1-4N2 according to $8^{\text {th }}$ TNM staging. The actuarial survival probability and conditional survival probability of these 9 groups were also explored. According to the results exhibited in Table 3, the worse the TNM stage, the lower the overall survival rate of cancers, for example, 5-year OS in T1aN0 cohort is $73 \%$ (95\%Cl: $72 \%-74 \%)$, T2aNO cohort is $54 \%$ (95\%Cl: $53 \%-55 \%)$, T3NO cohort is $46 \%(95 \% \mathrm{Cl}$ : $44 \%-47 \%)$, T4N0 cohort is $39 \%(95 \% \mathrm{Cl}: 37 \%-40.5 \%)$. Analysis based on conditional survival probability indicating that the worse the prognosis of those who survived the first few years of diagnosis, the more significant the improvement of the survival probability, and for patients with a relatively well initial prognosis, the corresponding increase in conditional survival probability is not obvious. For example, in the T4NO cohort, the 8-year OS rate is $30 \%$ (95\% Cl: $27 \%-32 \%)$, corresponding, for these who have survived for 5 years, the probability surviving another 3 years (according to the mathematical formula, it could be described as CS (8囚5)) is 78\%. The actuarial 8-year OS of T3NO cohort is $34 \%(95 \% \mathrm{Cl}: 31 \%-36 \%)$, corresponding, the CS (8囚5) was $74 \%(95 \% \mathrm{Cl}$ : $72 \%-75 \%)$. The actuarial 8-year OS of T1aN0 patients is $62 \%$ (95\% Cl: 60\%-64\%), corresponding, the CS (8囚5) was $85 \%$ (95\% Cl: $83 \%-86 \%$ ) (Difference is $23 \%$; $\mathrm{P}$ $<0.001$ ) (Figure 4A).

\section{Pathological types}

Other tumor prognostic factors were also explored in this study. Analysis based on pathological types showed that the prognosis of patients with adenocarcinoma is better than other types including squamous cell carcinoma, adenosquamous cell carcinoma and large cell carcinoma (Figure 4(A)). For those surviving in the first few years after diagnosis, the worse the prognosis of pathological types (such as squamous cell carcinoma (SCC), adenosquamous cell carcinoma (ACC), and large cell carcinoma (LCC)), the more significance the conditional survival probability benefit, for example, in the adenocarcinoma cohort ( 55,592$)$, the 8 -year OS is $46.3 \%$ (95\% Cl: $45 \%-47 \%)$, but the 8 -year survival rate for those who had survived 5 years after diagnosis is $79 \%(95 \% \mathrm{Cl}: 78 \%-80 \%)$, the difference is $22.7 \%$. Simultaneously, in the SCC cohort (n 24,062), the probabilities of CS(8) increased from $30.2 \%$ (95\% Cl: $29 \%-33 \%$ ) at baseline to $70 \%$ (95\% Cl: $67 \%-74 \%$ ) at 5 years of follow-up, the probabilities of CS(8) in the ACC cohort ( $\mathrm{n} 2,188)$ increased from $29.3 \%(95 \% \mathrm{Cl}: 27 \%-31 \%)$ at baseline to $72 \%(95 \% \mathrm{Cl}: 67 \%-76 \%)$ at 5 years of follow-up, and in the LCC cohort (n 3,712) increased from $29.4 \%$ at baseline to $74 \%$ at 5 years of follow-up (Figure 4(B) and Table 4). It indicated that the longer cancer patient survives, the more improvement of survival prognosis they would get, and the less significant the influence of pathology type on cancer prognosis.

\section{Tumor size}


Compared with the patients with tumor size less than $3 \mathrm{~cm}$ (5-year OS is $60.7 \%$ (95\% Cl: $59 \%-62 \%)$ ), the bigger tumor size shows a unsatisfactory 5 -year OS (the 5-year OS of $3.1-5.0 \mathrm{~cm}$ cohort, $5.1-7.0 \mathrm{~cm}$ cohort and more than $7.0 \mathrm{~cm}$ cohort were $45.7 \%$ (95\% Cl: $45 \%-46 \%), 39.3 \%(95 \% \mathrm{Cl}: 38 \%-40 \%)$ and $31.2 \%(95 \% \mathrm{Cl}$ : $30 \%-32 \%$ ) respectively) (Figure 4 (C)), the 8-year survival probability given that the patient has lived for the first 5 years after diagnosis in the less than $3 \mathrm{~cm}$ cohort, 3.1-5.0 cm cohort, $5.1-7.0 \mathrm{~cm}$ cohort and more than $7.0 \mathrm{~cm}$ cohort were $78 \%$ (95\% Cl: 77\%-79\%), 74\% (95\% Cl: 73\%-74\%), 74\% (95\% Cl: 72\%-76\%) and 76\% (95\% Cl: $73 \%-78 \%)$ respectively, which did not show a significant difference, indicating that, after a period of survival, patients with poor initial prognosis could obtain greater survival benefits when compared with those better initial prognoses (Figure 4(D)).

\section{Surgical intervention}

In this study, the approaches of surgical interventions included no surgery perform, local ablation or electrocautery, sublobar resection, lobectomy and others, the corresponding 5-year OS were $5.4 \%(95 \% \mathrm{Cl}$ : 5\%-6\%), 19.9\% (95\%Cl: 17\%-23\%), 48.2\% (95\% Cl: 47\%-49\%), 56.4\% (95\% Cl: 54\%-58\%) and $40.6 \%$ (95\%Cl: $37 \%-44 \%$ ) respectively (Figure $4(E)$ ), we also analyzed the 5-year survival probability of those who already lived for the first 2 years after diagnosis (CS (5囚2)), the CS (5囚2) of the above 5 interventions were $34 \%$ (95\%Cl: 30\%-38\%), 41\% (95\%Cl: 35\%-47\%), 66\% (95\%Cl: 65\%-68\%), 73\% (95\%Cl: 72\%-73\%) and 66\% (95\%Cl: $65 \%-68 \%)$ respectively ((Figure $4(\mathrm{~F})$ ) and Table 4), which demonstrated that the cancer prognosis increased rapidly for those who survived the first few years, this result greatly encourages cancer survivor.

\section{Patient age}

As shown in Figure 4(G), the 5-year OS of patients in different age groups are significantly different, specifically, the 5-year OS of those ages range from 15-45, 45-70 and over 70 years old were $77.1 \%, 56.1 \%$ and $41.8 \%$ respectively. For these had survived 5 years after surgery, The probability for living another 3 years (CS (8囚5)) were $93 \%(+15.9 \%)$ in patients aged $15-45$ years, $81 \%(+24.9 \%)$ in patients aged $45-70$ years and $65 \%(+23.2 \%)$ in patients aged $\geq 71$ years Figure $4(\mathrm{H})$, suggesting that the significant survival benefit would be got for those survived the first few years.

\section{Other pathological features}

Actuarial survival probability and condition survival probability of other pathological features were also analyzed including gender Figure 5(A-B), chemotherapy Figure 5(C-D), radiotherapy Figure 5(E-F), positive lymph nodes Figure 5(G-H), SEER stage Figure 6(A-B), primary tumor site Figure 6(C-D). The results showed that the chemotherapy cohort and the radiotherapy cohort, lymph node positives (more than 16), the SEER stage was regional, Caucasian, primary tumor site lie in whole lung or bronchus were associated with lower 5-year actuarial survival (Table 4). At the same time, time-dependent conditional survival probability was also explored, for example, patients in the female group had an actuarial 5-year OS of $57.4 \%$, while the 5 -year survival probability of these who had survived for 2 years (CS (5区2)) is $74 \%$. The 5year OS in the male cohort is $44 \%$, and the CS (5囚2) is $67 \%$ (Figure $5(B)$ ). Simultaneously, the 5 -year OS in the chemotherapy cohort is $42.1 \%$, and the CS (5区2) is $62 \%$, corresponding difference in the non- 
chemotherapy cohort is $19.6 \%$ (Figure 5(D)), patients in the radiotherapy cohort had an actuarial 5-year OS of $30.2 \%$ and a CS (5区2) of $54 \%$, The detailed overall survival rates and conditional survival probability of other tumor prognostic factors were showed in Table 4.

\section{Discussion}

The view that the risk of tumor-specific death decreases with the length of postoperative survival is called conditional survival. Conditional survival (CS) means that, on average, long-term cancer survivors have a better prognosis than newly diagnosed individuals [15-17], because most of the patients who survived after the first few years were those respond well to treatment, and the condition was alleviated, the complications were controlled, adverse reactions caused by surgery, radiotherapy and chemotherapy gradually weakened and the threat of death-related risks is gradually reduced [4].

The 5 -year overall survival rate of the enrolled patients is $51 \%$, For these who have survived $1-, 2-, 3-, 4$ - or 5 years after the diagnosis of cancer, the probability to survive another 3 years is $67 \%, 71 \%, 73 \%, 75 \%$ and $77 \%$ respectively, demonstrated that the survival probability increasing gradually as patients survive longer.

The results showed that the 5-year OS of patients with T1aN0 to T1-4N2 gradually decreases, range from $55 \%$ of $\mathrm{T} 1 \mathrm{aN0}$ to $17 \%$ of $\mathrm{T} 1-4 \mathrm{~N} 2$, which brought frustrating results to those patients initially diagnosed with advanced disease. However, it is gratifying to observe the significant improvement in CS as patients survive longer, especially for those with advanced disease. For example, the difference between 5 -year actuarial OS and CS (5区3) in T1aNO cohort is $15 \%, \mathrm{~T} 2 \mathrm{aNO}$ is $27 \%$, T3NO is $35 \%$, and T4NO is $39 \%$ (Figure. 4D). We can also note that, for these long-term cancer survivors, the difference in conditional survival probability of people with different $\mathrm{T}$ and $\mathrm{N}$ stages gradually narrowed, tending to be consistent. In other words, for these had survived 5 years after diagnosed, the probability of patients still alive in the tenth year in T1aN0, T2aN0, T3N0, T4N0, T1-4N1 are 76\%, 63\%, 64\%, 67\% and 60\% respectively, which revealed that the survival prognosis of patients is not only related to clinical pathological factors, but also to the survival time of patients after surgery, and as the survival time is prolonged, the prognosis of patients increasingly shows time dependence.

The results of the age-based grouping show that the survival prognosis of patients in different age groups varies greatly, the 5 -year OS of the elderly patients is the unsatisfactory $(32.4 \%)$, and the young patients is the best (46.5\%). In the $15-45$ cohorts, the 3 -year conditional survival probabilities increased from $83 \%$ at baseline to $93 \%$ at 60 months, in these aged more than 70 years old, the CS3 increased from $56 \%$ at baseline to $65 \%$ at 60 month. Compared with young patients and middle-aged patients, the improvement of conditional probability in elderly patients is not significant, which may be due to the long smoking time of elderly patients, the high incidence of cardiovascular diseases and respiratory diseases or the poor physical performance of elderly patients caused by.

Other tumor characteristics, including poor histological grade, larger tumor size, adenosquamous carcinoma, lymph node involvement, male, Caucasians, tumor located in the middle lobe and seed stage 
were associated with poor survival prognosis (Figure 6). However, from the perspective of long-term survival of patients, it may be more meaningful to explore the conditional survival probability and compare the actuarial OS and CS. Although unfavorable clinicopathological features show poor 5-year $\mathrm{OS}$, the benefit of conditional survival becomes very significance with the survival time of patient increases. For example, in the cohort of more than 16 lymph node metastasis, compared with the 5-year OS of all patients, those survived the first three years after diagnosis (CS (5区3)) shows a better 5-year survival rate, increased by $16 \%$ (55\%-71\%), while patients without lymph node metastasis increased by only $4 \%$ (75\%-79\%). Similarly, Patients with larger tumor diameters increased CS (8区5) by $26 \%$ and patients with smaller tumor diameters increased by only $5 \%$ (Figure 3 ). Those patients with adverse clinical factors did not pass the most critical period and died within the first few years, as the years of survival of specific patients increase, these adverse prognostic factors that affect the prognosis become increasingly unrelated. Therefore, our data suggests that CS may be a more valuable tool late in the postoperative period to estimate the prognosis of patients who are predicted to die based on initial actuarial estimates.

Some limitations of this study should not be overlooked. First, this study is a retrospective study. Inevitable deviations would be appear in the collection of clinical pathological characteristics, diagnosis and treatment of patients; second, the diagnosis of patients in this study the time span is large (20002016). The impact between lung cancer patients diagnosed in different periods and the prognosis has not been explored. Third, multiple primary tumors were excluded in order to eliminate interference, but the errors were unavoidable in reclassified the $\mathrm{T}$ stage and $\mathrm{N}$ stage. Nonetheless, this study also proposes a dynamic assessment of the conditional survival probability of lung cancer patients, thereby allowing adjustment of the predicted survival time after lung resection. The tool may prove useful to patients, doctors and researchers, and will guide dynamic and personalized clinical management decisions.

\section{Conclusion}

The worse the initial diagnosis of cancer patient, the more significant the benefit of time-dependent conditional survival probability, long-lived cancer patients may have a better cancer prognosis.

\section{Abbreviations}

NSCLC: non-small cell lung cancer

SEER: Surveillance, Epidemiology, and End Results

CS: condition survival probability

OS: overall survival

AJCC: American Joint Committee on Cancer

SCC:squamous cell carcinoma 
ACC: adenosquamous cell carcinoma

LCC:and large cell carcinoma

\section{Declarations}

\section{Ethics approval and consent to participate}

This manuscript does not involve animal and the SEER database is a public database, analysis of lung cancer patients does not require informed consent and institutional review. So it has not yet applied the Ethics approval and consent to participate.

\section{Consent for publication}

Not applicable.

\section{Availability of data and materials}

The datasets supporting the conclusions of this article were included within the article

\section{Conflict of interest}

The authors declare no conflict of interest.

\section{Founding}

This research was supported by the National Natural Science Foundation of China (grant number 81960532).

\section{Author contributions}

Project design: Gang Xu and Hongling Lu;

Searched databases and performed literature screen: Shixu Fang and Xixian Ke;

Data extraction and analysis: Kui Zhai and Hao Han;

Evaluated the quality of included literature: Shixu Fang;

Manuscript writing: Gang Xu, Shixu Fang, XixianKe and Hongling Lu.

Final draft was approved by all the authors.

\section{Acknowledgments}

Not applicable. 
Authors' informations

${ }^{1}$ Department of Thoracic Surgery, The Affiliated Hospital of Zunyi medical university, 149 Dalian road, Zunyi, Guizhou, 563000, China

${ }^{2}$ Department of biochemistry, Zunyi medical university, No.6 xuefu west road, xinpu new area, Zunyi, Guizhou, 563099, China

\section{References}

1. Feinstein AR, Sosin DM, Wells CK: The Will Rogers phenomenon. Stage migration and new diagnostic techniques as a source of misleading statistics for survival in cancer. The New England journal of medicine 1985, 312(25):1604-1608.

2. FL G: TNM: our language of cancer. CA: a cancer journal for clinicians 2004, 54(3):129-130.

3. Skuladottir $\mathrm{H}$, Olsen $\mathrm{JH}$ : Conditional survival of patients with the four major histologic subgroups of lung cancer in Denmark. Journal of clinical oncology : official journal of the American Society of Clinical Oncology 2003, 21(16):3035-3040.

4. Zabor EC, Gonen M, Chapman PB, Panageas KS: Dynamic prognostication using conditional survival estimates. Cancer 2013, 119(20):3589-3592.

5. Hieke S, Kleber M, König C, Engelhardt M, Schumacher M: Conditional Survival: A Useful Concept to Provide Information on How Prognosis Evolves over Time. Clinical cancer research : an official journal of the American Association for Cancer Research 2015, 21(7):1530-1536.

6. Wang P, Sun Z, Wang W, Deng J, Wang Z: Conditional survival of patients with gastric cancer who undergo curative resection: A multi-institutional analysis in China. 2018, 124(5):916-924.

7. van Erning FN, van Steenbergen LN, Lemmens V, Rutten HJT, Martijn H, van Spronsen DJ, JanssenHeijnen MLG: Conditional survival for long-term colorectal cancer survivors in the Netherlands: who do best? European journal of cancer (Oxford, England : 1990) 2014, 50(10):1731-1739.

8. Zhong Q, Chen QY, Li P, Xie JW, Wang JB, Lin JX, Lu J, Cao LL, Lin M, Tu RH et al: Prediction of Conditional Probability of Survival After Surgery for Gastric Cancer: A Study Based on Eastern and Western Large Data Sets. Surgery 2018, 163(6):1307-1316.

9. Ito Y, Miyashiro I, Ito H, Hosono S, Chihara D, Nakata-Yamada K, Nakayama M, Matsuzaka M, Hattori $\mathrm{M}$, Sugiyama $\mathrm{H}$ et al: Long-term survival and conditional survival of cancer patients in Japan using population-based cancer registry data. Cancer science 2014, 105(11):1480-1486.

10. Thuret R, Sun M, Abdollah F, Schmitges J, Shariat SF, Iborra F, Guiter J, Patard JJ, Perrotte P, Karakiewicz PI: Conditional survival predictions after surgery for patients with penile carcinoma. Cancer 2011, 117(16):3723-3730.

11. Kurta ML, Edwards RP, Moysich KB, McDonough K, Bertolet M, Weissfeld JL, Catov JM, Modugno F, Bunker $\mathrm{CH}$, Ness RB et al: Prognosis and conditional disease-free survival among patients with 
ovarian cancer. Journal of clinical oncology : official journal of the American Society of Clinical Oncology 2014, 32(36):4102-4112.

12. Palumbo C, Mistretta FA, Knipper S, Pecoraro A, Tian Z, Shariat SF, Saad F, Simeone C, Briganti A, Antonelli A et al: Conditional Survival of Patients With Nonmetastatic Renal Cell Carcinoma: How Cancer-Specific Mortality Changes After Nephrectomy. Journal of the National Comprehensive Cancer Network : JNCCN2020, 18(1):44-51.

13. Huang JF, Chen D, Zheng XQ, Lin JL, Wang XY, Wu AM: Conditional survival and changing risk profile in patients with chordoma: a population-based longitudinal cohort study. 2019, 14(1):181.

14. Cronin KA, Ries LA, Edwards BK: The Surveillance, Epidemiology, and End Results (SEER) Program of the National Cancer Institute. Cancer 2014, 120 Suppl 23:3755-3757.

15. Latenstein AEJ, van Roessel S, van der Geest LGM, Bonsing BA, Dejong CHC, Groot Koerkamp B, de Hingh I, Homs MYV, Klaase JM, Lemmens V et al: Conditional Survival After Resection for Pancreatic Cancer: A Population-Based Study and Prediction Model. Annals of surgical oncology 2020.

16. Chen QY, Zhong Q, Zhou JF, Qiu XT, Dang XY, Cai LS, Su GQ, Xu DB, Lin GT, Guo KQ et al: Conditional survival and recurrence of remnant gastric cancer after surgical resection: A multi-institutional study. Cancer science 2020, 111(2):502-512.

17. Yan L, Chen F, Chen L, Lin J, Chen Q, Bao X, Qiu Y, Lin L, Zheng X, Pan L et al: Dynamic evaluation of conditional survival in patients with oral squamous cell carcinoma after surgical resection: A largescale prospective study. Oral oncology 2020, 104:104639.

\section{Tables}

Table 1: Baseline characteristics of enrolled patients with NSCLC in the SEER database. 


\begin{tabular}{|c|c|}
\hline Variables & Total cohort, $\mathrm{n}(\%)$ \\
\hline No. patients (\%) & 95531 \\
\hline Mean (median) age, years & $62(62)$ \\
\hline \multicolumn{2}{|l|}{ Age } \\
\hline $15-45$ years & $3046(3.2)$ \\
\hline $46-70$ years & $51191(53.6)$ \\
\hline$\geq 70$ years & $40494(43.2)$ \\
\hline \multicolumn{2}{|l|}{ Gender, n (\%) } \\
\hline Female & $48668(50.9)$ \\
\hline Male & $46863(49.1)$ \\
\hline \multicolumn{2}{|l|}{ Race, n (\%) } \\
\hline White & $81013(84.8)$ \\
\hline Black & $8127(8.5)$ \\
\hline other & $6391(6.7)$ \\
\hline \multicolumn{2}{|c|}{$8^{\text {th }}$ AJCC* pathological stage, $n(\%)$} \\
\hline 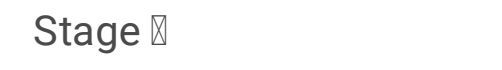 & $52478(54.9)$ \\
\hline 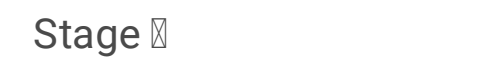 & $18726(19.6)$ \\
\hline 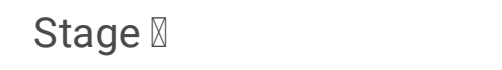 & $19136(20)$ \\
\hline Unknown & $5191(5.5)$ \\
\hline \multicolumn{2}{|l|}{ Pathological T stage, n (\%) } \\
\hline pT1 & $53086(55.5)$ \\
\hline pT2 & $22645(23.7)$ \\
\hline pT3 & $8330(8.7)$ \\
\hline pT4 & $11470(12.1)$ \\
\hline \multicolumn{2}{|l|}{ Pathological N stage, n (\%) } \\
\hline $\mathrm{pN} 0 / \mathrm{pNx}$ & $71968(75.3)$ \\
\hline $\mathrm{pN} 1$ & $12021(12.6)$ \\
\hline $\mathrm{pN} 2$ & $11517(12.1)$ \\
\hline pN3 & $25(0.026)$ \\
\hline
\end{tabular}

Page 12/27 


\begin{tabular}{|c|c|}
\hline \multicolumn{2}{|l|}{ Tumour grade, $\mathrm{n}(\%)$} \\
\hline grade $\mathbb{Z}$ & $12681(13.5)$ \\
\hline grade $\mathbb{Z}$ & $34063(35.7)$ \\
\hline 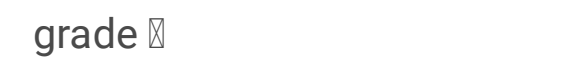 & 31540 (33) \\
\hline grade $\mathbb{Z}$ & $2390(2.5)$ \\
\hline Unknown & $14857(15.3)$ \\
\hline \multicolumn{2}{|l|}{ Tumour size, n (\%) } \\
\hline$\leq 30 \mathrm{~mm}$ & $53086(55.5)$ \\
\hline $31-50 \mathrm{~mm}$ & $22645(23.7)$ \\
\hline $51-70 \mathrm{~mm}$ & $8330(8.7)$ \\
\hline$\geq 71 \mathrm{~mm}$ & $4982(5.2)$ \\
\hline Unknown & $6268(6.5)$ \\
\hline \multicolumn{2}{|l|}{ Histological subtype, n (\%) } \\
\hline Adenocarcinoma & $55592(49.1)$ \\
\hline Squamous cell carcinoma & $24062(25.2)$ \\
\hline Adenosquamous carcinoma & $2188(2.3)$ \\
\hline Large cell carcinoma & $3712(3.9)$ \\
\hline Other & $18676(19.5)$ \\
\hline \multicolumn{2}{|l|}{ Primary tumor site } \\
\hline Upper lobe & $53757(56.3)$ \\
\hline Middle lobe & $5213(5.5)$ \\
\hline Lower lobe & $29529(30.1)$ \\
\hline Other & $7032(7.1)$ \\
\hline \multicolumn{2}{|l|}{ Type of surgery } \\
\hline local distribution or excision & $722(0.75)$ \\
\hline Sublobar resection & $14615(15.3)$ \\
\hline Lobectomy & $65951(59)$ \\
\hline Resection of whole lung & $9897(10.4)$ \\
\hline No surgery & $4346(4.5)$ \\
\hline
\end{tabular}




\begin{tabular}{|l|l|}
\hline 0 & $59473(62.3)$ \\
\hline $1-15$ & $19657(20.6)$ \\
\hline Radiation & $16401(17.1)$ \\
\hline Yes & $13133(13.7)$ \\
\hline No & $82398(86.3)$ \\
\hline Chemotherapy & \\
\hline Yes & $22530(23.6)$ \\
\hline No & $73001(76.4)$ \\
\hline Seer stage & $47912(50.2)$ \\
\hline local & $43359(45.4)$ \\
\hline regional & $4260(4.4)$ \\
\hline Unknown & \\
\hline
\end{tabular}

Table 2: Probability of patients with NSCLC resection can reach a certain survival time after a period of survival. 
Years already survived

Survival 0 Year 1 Year 2 Year 3 Year 4 Year 5 Year 6 Year 7 Year 8 Year probability to reach $\mathrm{X}$ years

\begin{tabular}{|c|c|c|c|c|c|c|c|c|c|}
\hline 1 Year & $\begin{array}{l}0.84 \\
(0.83- \\
0.84)\end{array}$ & 1 & & & & & & & \\
\hline 2 Year & $\begin{array}{l}0.72 \\
(0.72- \\
0.72)\end{array}$ & $\begin{array}{l}0.86 \\
(0.86- \\
0.86)^{a}\end{array}$ & 1 & & & & & & \\
\hline 3 Year & $\begin{array}{l}0.63 \\
(0.63- \\
0.63)\end{array}$ & $\begin{array}{l}0.75 \\
(0.75- \\
0.76)\end{array}$ & $\begin{array}{l}0.88 \\
(0.87- \\
0.88)\end{array}$ & 1 & & & & & \\
\hline 4 Year & $\begin{array}{l}0.56 \\
(0.56- \\
0.57)\end{array}$ & $\begin{array}{l}0.67 \\
(0.67- \\
0.68)\end{array}$ & $\begin{array}{l}0.78 \\
(0.78- \\
0.79)\end{array}$ & $\begin{array}{l}0.89 \\
(0.89- \\
0.90)\end{array}$ & 1 & & & & \\
\hline 5 Year & $\begin{array}{l}0.51 \\
(0.51- \\
0.51)\end{array}$ & $\begin{array}{l}0.61 \\
(0.60- \\
0.61)\end{array}$ & $\begin{array}{l}0.71 \\
(0.70- \\
0.71)\end{array}$ & $\begin{array}{l}0.81 \\
(0.80- \\
0.81)\end{array}$ & $\begin{array}{l}0.90 \\
(0.90- \\
0.91)\end{array}$ & 1 & & & \\
\hline 6 Year & $\begin{array}{l}0.46 \\
(0.46- \\
0.47)\end{array}$ & $\begin{array}{l}0.55 \\
(0.55- \\
0.56)\end{array}$ & $\begin{array}{l}0.64 \\
(0.64- \\
0.65)\end{array}$ & $\begin{array}{l}0.73 \\
(0.73- \\
0.74)\end{array}$ & $\begin{array}{l}0.82 \\
(0.82- \\
0.83)\end{array}$ & $\begin{array}{l}0.91 \\
(0.91- \\
0.91)\end{array}$ & 1 & & \\
\hline 7 Year & $\begin{array}{l}0.42 \\
(0.42- \\
0.43)\end{array}$ & $\begin{array}{l}0.51 \\
(0.50- \\
0.51)\end{array}$ & $\begin{array}{l}0.59 \\
(0.59- \\
0.59)\end{array}$ & $\begin{array}{l}0.67 \\
(0.67- \\
0.68)\end{array}$ & $\begin{array}{l}0.75 \\
(0.75- \\
0.76)\end{array}$ & $\begin{array}{l}0.83 \\
(0.83- \\
0.84)\end{array}$ & $\begin{array}{l}0.92 \\
(0.91- \\
0.92)\end{array}$ & 1 & \\
\hline 8 Year & $\begin{array}{l}0.39 \\
(0.38- \\
0.39)\end{array}$ & $\begin{array}{l}0.47 \\
(0.46- \\
0.47)\end{array}$ & $\begin{array}{l}0.54 \\
(0.54- \\
0.55)\end{array}$ & $\begin{array}{l}0.62 \\
(0.61- \\
0.62)\end{array}$ & $\begin{array}{l}0.69 \\
(0.69- \\
0.70)\end{array}$ & $\begin{array}{l}0.77 \\
(0.76- \\
0.77)\end{array}$ & $\begin{array}{l}0.84 \\
(0.84- \\
0.85)\end{array}$ & $\begin{array}{l}0.92 \\
(0.91- \\
0.92)\end{array}$ & 1 \\
\hline 9 Year & $\begin{array}{l}0.36 \\
(0.35- \\
0.36)\end{array}$ & $\begin{array}{l}0.43 \\
(0.42- \\
0.43)\end{array}$ & $\begin{array}{l}0.50 \\
(0.49- \\
0.50)\end{array}$ & $\begin{array}{l}0.57 \\
(0.56- \\
0.58)\end{array}$ & $\begin{array}{l}0.64 \\
(0.63- \\
0.64)\end{array}$ & $\begin{array}{l}0.71 \\
(0.70- \\
0.71)\end{array}$ & $\begin{array}{l}0.78 \\
(0.77- \\
0.78)\end{array}$ & $\begin{array}{l}0.85 \\
(0.84- \\
0.85)\end{array}$ & $\begin{array}{l}0.92 \\
(0.92- \\
0.93)\end{array}$ \\
\hline 10 Year & $\begin{array}{l}0.33 \\
(0.33- \\
0.34)^{a}\end{array}$ & $\begin{array}{l}0.40 \\
(0.39- \\
0.40)\end{array}$ & $\begin{array}{l}0.46 \\
(0.46- \\
0.47)\end{array}$ & $\begin{array}{l}0.53 \\
(0.52- \\
0.53)\end{array}$ & $\begin{array}{l}0.59 \\
(0.58- \\
0.60)\end{array}$ & $\begin{array}{l}0.65 \\
(0.65- \\
0.66)^{a}\end{array}$ & $\begin{array}{l}0.72 \\
(0.71- \\
0.72)\end{array}$ & $\begin{array}{l}0.78 \\
(0.78- \\
0.79)\end{array}$ & $\begin{array}{l}0.85 \\
(0.85- \\
0.86)\end{array}$ \\
\hline $\begin{array}{l}\text { number at } \\
\text { risk }\end{array}$ & 95531 & 74924 & 59279 & 47592 & 38626 & 31546 & 25838 & 21029 & 17207 \\
\hline
\end{tabular}

${ }^{a}$ For example, if patients had survived for 1 year, the probability to survived another 1 year is $86 \%$. If patients had survived for 5 year after diagnosis, the survival probability of 10 -year is $65 \%$, and the 10 -year survival probability for these initial diagnosis of cancer is $33 \%$.

Table 3: Actual survival rates of 5-15 years, Conditional 5-Year probability based on surviving years and Survival Gains After Surgery according to AJCC 8th. 
Actual survival, Conditional 5-Year and Survival Gains After Surgery according to AJCC 8th

Years already survived

$\begin{array}{llllllllll}\text { Cohort } & 0 & 1 & 2 & 3 & 4 & 5 & 6 & 8 & 10\end{array}$

T1aNo

$\begin{array}{llllllllll}\begin{array}{l}\text { Conditional 5-y } \\ \text { survival }\end{array} & 73 & 74 & 74^{\mathrm{a}} & 75 & 76 & 76 & 76 & 75 & 76\end{array}$
probability, \% ${ }^{\text {a }}$

$\begin{array}{llllllllll}\text { number at risk, } & 4499 & 3800 & 3205 & 2723 & 2271 & 1896 & 1615 & 1115 & 687\end{array}$
$\mathrm{n}^{\mathrm{b}}$

\begin{tabular}{|c|c|c|c|c|c|c|c|c|c|}
\hline survival gain, $\%^{\mathrm{c}}$ & - & +1 & 0 & +1 & +1 & 0 & 0 & -1 & +1 \\
\hline $\begin{array}{l}\text { Actual survival } \\
\text { rate, } \% \mathrm{~d}\end{array}$ & $73^{d}$ & 69 & 65 & 62 & 59 & $55^{d}$ & 52 & 47 & 42 \\
\hline
\end{tabular}

$\begin{array}{llllllllll}\begin{array}{c}\text { Conditional 5-y } \\ \text { survival }\end{array} & 69 & 68 & 68 & 69 & 69 & 69 & 70 & 69 & 68 \\ \text { probability \% }\end{array}$

probability, \% ${ }^{\mathrm{a}}$

\begin{tabular}{|c|c|c|c|c|c|c|c|c|c|}
\hline $\begin{array}{l}\text { number at risk, } \\
\mathrm{n}^{\mathrm{b}}\end{array}$ & 21138 & 18108 & 15364 & 12873 & 10756 & 8906 & 7358 & 4911 & 2975 \\
\hline survival gain, $\%^{\mathrm{c}}$ & - & -1 & 0 & +1 & 0 & 0 & +1 & -1 & -1 \\
\hline $\begin{array}{l}\text { Actual survival } \\
\text { rate, \% }{ }^{\mathrm{d}}\end{array}$ & 69 & 64 & 59 & 55 & 51 & 48 & 44 & 38 & 33 \\
\hline
\end{tabular}

\begin{tabular}{|c|c|c|c|c|c|c|c|c|c|}
\hline $\begin{array}{l}\text { Conditional 5-y } \\
\text { survival } \\
\text { probability, \%a }\end{array}$ & 61 & 61 & 62 & 63 & 65 & 65 & 66 & 66 & 64 \\
\hline
\end{tabular}

\begin{tabular}{|lllllllllll|}
\hline $\begin{array}{c}\text { number at risk, } \\
\mathrm{n}^{\mathrm{b}}\end{array}$ & 17254 & 14548 & 12077 & 9974 & 8221 & 6771 & 5550 & 3555 & 2268 \\
\hline $\begin{array}{l}\text { survival gain, \% } \\
\text { c }\end{array}$ & - & 0 & +1 & +1 & +2 & 0 & +1 & 0 & -2 \\
\hline $\begin{array}{l}\text { Actual survival } \\
\text { rate, \% }\end{array}$ & 61 & 55 & 51 & 46 & 43 & 40 & 36 & 31 & 25 \\
\hline $\begin{array}{l}\text { T2aN0 } \\
\begin{array}{l}\text { Conditional 5-y } \\
\text { survival } \\
\text { probability, \% }\end{array}\end{array}$ & 54 & 57 & 59 & 61 & 62 & 63 & 62 & 63 & 62 \\
\hline
\end{tabular}




\begin{tabular}{|c|c|c|c|c|c|c|c|c|c|}
\hline $\begin{array}{l}\text { number at risk, } \\
\mathrm{n}^{\mathrm{b}}\end{array}$ & 9587 & 7820 & 6384 & 5137 & 4187 & 3436 & 2823 & 1844 & 1144 \\
\hline survival gain, \%c & - & +3 & +2 & +2 & +1 & +1 & -1 & +1 & -1 \\
\hline $\begin{array}{l}\text { Actual survival } \\
\text { rate, \%d }\end{array}$ & 54 & 49 & 45 & 41 & 37 & 34 & 31 & 26 & 21 \\
\hline \multicolumn{10}{|l|}{ T2bN0 } \\
\hline $\begin{array}{l}\text { Conditional 5-y } \\
\text { survival } \\
\text { probability, \%a }\end{array}$ & 50 & 55 & 59 & 61 & 63 & 62 & 61 & 63 & 66 \\
\hline
\end{tabular}

\begin{tabular}{|c|c|c|c|c|c|c|c|c|c|}
\hline $\begin{array}{l}\text { number at risk, } \\
n^{\mathrm{b}}\end{array}$ & 5100 & 4034 & 3198 & 2606 & 2104 & 1746 & 1447 & 944 & 583 \\
\hline survival gain, \%c & - & +5 & +4 & +2 & +2 & -1 & -1 & +2 & +3 \\
\hline $\begin{array}{l}\text { Actual survival } \\
\text { rate, } \% \mathrm{~d}\end{array}$ & 50 & 45 & 42 & 38 & 35 & 31 & 28 & 24 & 21 \\
\hline
\end{tabular}

\begin{tabular}{|c|c|c|c|c|c|c|c|c|c|}
\hline $\begin{array}{l}\text { Conditional 5-y } \\
\text { survival } \\
\text { probability, \%a }\end{array}$ & 46 & 52 & 58 & 60 & 63 & 64 & 65 & 64 & 60 \\
\hline $\begin{array}{l}\text { number at risk, } \\
\mathrm{n}^{\mathrm{b}}\end{array}$ & 4790 & 3628 & 2784 & 2197 & 1802 & 1489 & 1223 & 810 & 525 \\
\hline survival gain, \%c & - & +6 & +6 & +2 & +3 & +1 & +1 & -1 & -4 \\
\hline $\begin{array}{l}\text { Actual survival } \\
\text { rate, \% } \mathrm{d}\end{array}$ & 46 & 42 & 38 & 34 & 32 & 30 & 27 & 22 & 18 \\
\hline
\end{tabular}

T4NO

$\begin{array}{llllllllll}\begin{array}{c}\text { Conditional 5-y } \\ \text { survival }\end{array} & 39 & 47 & 56 & 61 & 65 & 67 & 68 & 68 & 67\end{array}$
probability, \%a

$\begin{array}{lccccccccc}\begin{array}{l}\text { number at risk, } \\ \mathrm{n}^{\mathrm{b}}\end{array} & 4409 & 3135 & 2310 & 1795 & 1455 & 1186 & 989 & 691 & 470 \\ \begin{array}{l}\text { survival gain, \% c } \\ \begin{array}{l}\text { Actual survival } \\ \text { rate, \% }\end{array}\end{array} & - & +8 & +9 & +5 & +4 & +2 & +1 & 0 & -1 \\ \end{array}$

T1-4N1

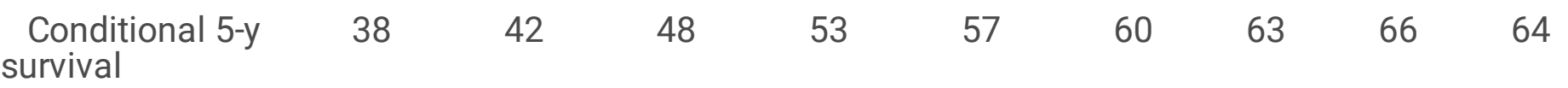




\begin{tabular}{|c|c|c|c|c|c|c|c|c|c|}
\hline $\begin{array}{l}\text { number at risk, } \\
\mathrm{n}^{\mathrm{b}}\end{array}$ & 12021 & 9183 & 6728 & 5083 & 3893 & 3058 & 2405 & 1542 & 949 \\
\hline survival gain, $\%^{\mathrm{c}}$ & - & +4 & +6 & +5 & +4 & +3 & +3 & +3 & +1 \\
\hline $\begin{array}{l}\text { Actual survival } \\
\text { rate, } \%^{d}\end{array}$ & 38 & 33 & 30 & 27 & 25 & 23 & 21 & 18 & 15 \\
\hline \multicolumn{10}{|l|}{ T1-4N2 } \\
\hline $\begin{array}{l}\text { Conditional 5-y } \\
\text { survival } \\
\text { probability, \% }{ }^{a}\end{array}$ & 30 & 35 & 42 & 48 & 53 & 57 & 59 & 62 & 64 \\
\hline $\begin{array}{l}\text { number at risk, } \\
\mathrm{n}^{\mathrm{b}}\end{array}$ & 11517 & 8316 & 5690 & 4072 & 3051 & 2361 & 1853 & 1133 & 669 \\
\hline survival gain, $\%^{\mathrm{c}}$ & - & +5 & +7 & +6 & +5 & +4 & +2 & +3 & +2 \\
\hline $\begin{array}{l}\text { Actual survival } \\
\text { rate, } \%^{d}\end{array}$ & 30 & 27 & 23 & 21 & 19 & 17 & 16 & 13 & 11 \\
\hline \multicolumn{10}{|l|}{ Abbreviation: } \\
\hline \multicolumn{10}{|c|}{$\begin{array}{l}\text { a The conditional } 5 \text {-year survival probability for these already survived } 2 \text { years in T1aN0 cohort, which } \\
\text { means that if patients had survived } 2 \text { years after diagnosis, the probability of still alive in the seventh } \\
\text { year after diagnosis is } 74 \% \text { (Purple background). } \\
\text { b At the beginning of the interval } \\
\text { cRelative to the previous year; } \\
\text { d For example, the } 5 \text {-year overall survival rate in T1aN0 cohort is } 73 \%, 10 \text {-year overall survival rate in } \\
\text { T1aN0 cohort is } 55 \% \text { (Red background). }\end{array}$} \\
\hline
\end{tabular}

Table 4: Conditional probability of survival for a few years after having survived for a certain years since diagnosed according to tumor prognostic factors. 


\begin{tabular}{|c|c|c|c|c|c|c|c|c|c|}
\hline \multirow[b]{2}{*}{ Variables } & \multicolumn{4}{|c|}{$\begin{array}{l}\text { 1-, 3-, 5-, 8-year OS rates, } \\
(\%)\end{array}$} & \multicolumn{5}{|c|}{ 3-year conditional survival probability, $(\%)^{a}$} \\
\hline & $\begin{array}{l}1- \\
\text { year } \\
\text { OS }\end{array}$ & $\begin{array}{l}\text { 3- } \\
\text { year } \\
\text { OS }\end{array}$ & $\begin{array}{l}5- \\
\text { year } \\
\text { OS }\end{array}$ & $\begin{array}{l}\text { 8- } \\
\text { year } \\
\text { OS }\end{array}$ & $\begin{array}{l}1 \mathrm{y} \\
\text { after } \\
\text { surgery }\end{array}$ & $\begin{array}{l}2 \mathrm{y} \\
\text { after } \\
\text { surgery }\end{array}$ & $\begin{array}{l}3 y \\
\text { after } \\
\text { surgery }\end{array}$ & $\begin{array}{l}4 \mathrm{y} \\
\text { after } \\
\text { surgery }\end{array}$ & $\begin{array}{l}5 y \\
\text { after } \\
\text { surgery }\end{array}$ \\
\hline All patients & 83.5 & 63.6 & 50.8 & 38.8 & 67 & 71 & 73 & 75 & 77 \\
\hline \multicolumn{10}{|l|}{ Age } \\
\hline $15-45$ years & 94.1 & 83.9 & 77.1 & 71.8 & 85 & 88 & 89 & 91 & 93 \\
\hline $46-70$ years & 87.2 & 68.1 & 56.2 & 45.7 & 70 & 74 & 77 & 80 & 81 \\
\hline$\geq 70$ years & 78.1 & 56.3 & 41.8 & 27.4 & 61 & 64 & 66 & 67 & 65 \\
\hline \multicolumn{10}{|l|}{ Gender (\%) } \\
\hline Female & 87.5 & 69.2 & 57.4 & 45.3 & 72 & 74 & 76 & 78 & 79 \\
\hline Male & 79.5 & 56.5 & 44 & 32.3 & 62 & 67 & 70 & 72 & 73 \\
\hline \multicolumn{10}{|l|}{ Race (\%) } \\
\hline White & 83.1 & 62.4 & 50.4 & 38.4 & 67 & 71 & 73 & 75 & 76 \\
\hline Black & 83.7 & 62.3 & 49.7 & 38.1 & 66 & 70 & 73 & 75 & 77 \\
\hline other & 88.6 & 69.7 & 56.7 & 44.5 & 71 & 72 & 73 & 76 & 79 \\
\hline \multicolumn{10}{|l|}{$\begin{array}{l}8^{\text {th }} \text { AJCC* } \\
\text { pathological } \\
\text { stage(\%) }\end{array}$} \\
\hline 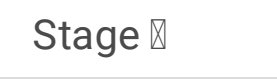 & 91.4 & 75.9 & 63.8 & 50.1 & 76 & 76 & 77 & 78 & 78 \\
\hline Stage $\otimes$ & 81.8 & 55.9 & 42.2 & 30.7 & 59 & 64 & 67 & 71 & 73 \\
\hline Stage $\rrbracket$ & 75 & 44.9 & 32.6 & 23.6 & 50 & 58 & 64 & 70 & 72 \\
\hline Unknown & 42.8 & 22.3 & 14.8 & 10 & 43 & 50 & 57 & 61 & 68 \\
\hline \multicolumn{10}{|l|}{$\begin{array}{l}\text { Pathological T } \\
\text { stage (\%) }\end{array}$} \\
\hline pT1 & 90.6 & 73.5 & 60.7 & 47.3 & 73 & 74 & 76 & 77 & 78 \\
\hline pT2 & 82.8 & 58.5 & 45.7 & 33.9 & 62 & 66 & 70 & 73 & 74 \\
\hline pT3 & 76.3 & 50.4 & 39.3 & 28.9 & 57 & 65 & 70 & 73 & 74 \\
\hline pT4 & 57.9 & 33.4 & 24.6 & 18.2 & 49 & 59 & 65 & 71 & 74 \\
\hline \multicolumn{10}{|l|}{$\begin{array}{l}\text { Tumour grade } \\
(\%)\end{array}$} \\
\hline grade $\mathbb{Z}$ & 94.1 & 83.5 & 74 & 61.4 & 84 & 83 & 84 & 84 & 83 \\
\hline
\end{tabular}




\begin{tabular}{|c|c|c|c|c|c|c|c|c|c|}
\hline grade $\otimes$ & 88.3 & 67.1 & 52.9 & 39.1 & 67 & 69 & 71 & 73 & 74 \\
\hline grade $\otimes$ & 80.5 & 55.6 & 43.1 & 31.6 & 60 & 66 & 69 & 72 & 74 \\
\hline grade $\otimes$ & 74.7 & 49.9 & 39.6 & 29.5 & 59 & 68 & 73 & 74 & 74 \\
\hline \multicolumn{10}{|l|}{ Unknown } \\
\hline \multicolumn{10}{|l|}{ Tumour size (\%) } \\
\hline$\leq 30 \mathrm{~mm}$ & 90.6 & 73.5 & 60.7 & 47.3 & 73 & 74 & 76 & 77 & 78 \\
\hline $31-50 \mathrm{~mm}$ & 82.8 & 58.5 & 45.7 & 33.9 & 62 & 66 & 70 & 73 & 74 \\
\hline $51-70 \mathrm{~mm}$ & 76.3 & 50.4 & 39.3 & 28.9 & 57 & 65 & 70 & 73 & 72 \\
\hline$\geq 71 \mathrm{~mm}$ & 69.8 & 40.9 & 31.2 & 23.6 & 50 & 61 & 68 & 74 & 76 \\
\hline Unknown & 47.7 & 26.6 & 18.7 & 13.7 & & & & & \\
\hline \multicolumn{10}{|l|}{$\begin{array}{l}\text { Histological } \\
\text { subtype (\%) }\end{array}$} \\
\hline Adenocarcinoma & 89.7 & 71.3 & 58.6 & 46.3 & 72 & 73 & 76 & 78 & 79 \\
\hline $\begin{array}{l}\text { Squamous cell } \\
\text { carcinoma }\end{array}$ & 79.9 & 55.8 & 43.3 & 30.2 & 61 & 66 & 69 & 69 & 70 \\
\hline $\begin{array}{l}\text { Adenosquamous } \\
\text { carcinoma }\end{array}$ & 80.3 & 52.8 & 40.5 & 29.3 & 45 & 52 & 68 & 72 & 72 \\
\hline $\begin{array}{l}\text { Large cell } \\
\text { carcinoma }\end{array}$ & 75.8 & 50.7 & 39.7 & 29.4 & 59 & 67 & 72 & 74 & 74 \\
\hline \multicolumn{10}{|l|}{ Other } \\
\hline \multicolumn{10}{|l|}{$\begin{array}{l}\text { Primary tumor } \\
\text { site }\end{array}$} \\
\hline Upper lobe & 85.9 & 65.1 & 52.6 & 40.1 & 68 & 71 & 73 & 75 & 76 \\
\hline Middle lobe & 89.8 & 72 & 59.5 & 48.3 & 73 & 75 & 77 & 80 & 81 \\
\hline Lower lobe & 85.3 & 64.3 & 51.8 & 39.2 & 67 & 71 & 73 & 75 & 76 \\
\hline Overlapping & 53.7 & 34.6 & 26.8 & 21 & 56 & 64 & 71 & 76 & 78 \\
\hline \multicolumn{10}{|l|}{ Type of surgery } \\
\hline $\begin{array}{l}\text { local } \\
\text { distribution or } \\
\text { excision }\end{array}$ & 66.4 & 36.5 & 19.9 & 11.5 & 41 & 41 & 47 & 53 & 58 \\
\hline $\begin{array}{l}\text { Sublobar } \\
\text { resection }\end{array}$ & 85.1 & 62.6 & 48.2 & 34.3 & 64 & 66 & 68 & 70 & 71 \\
\hline
\end{tabular}




\begin{tabular}{|c|c|c|c|c|c|c|c|c|c|}
\hline Lobectomy & 88.2 & 68.7 & 56.4 & 43.8 & 70 & 73 & 75 & 77 & 78 \\
\hline $\begin{array}{l}\text { Resection of } \\
\text { whole lung }\end{array}$ & 76.4 & 51.5 & 40.6 & 31.1 & 59 & 66 & 71 & 75 & 77 \\
\hline No surgery & 29.2 & 10.1 & 5.4 & 3.7 & 26 & 34 & 44 & 53 & 68 \\
\hline \multicolumn{10}{|l|}{$\begin{array}{l}\text { Number of } \\
\text { positive lymph } \\
\text { node }\end{array}$} \\
\hline 0 & 89.7 & 73.3 & 61.8 & 48.7 & 75 & 76 & 78 & 78 & 79 \\
\hline $1-15$ & 79.4 & 49.1 & 34.8 & 24.5 & 51 & 57 & 62 & 67 & 70 \\
\hline$\geq 16$ & 66.5 & 43.2 & 31.5 & 22.2 & 55 & 60 & 64 & 68 & 71 \\
\hline \multicolumn{10}{|l|}{ Radiation } \\
\hline Yes & 76.9 & 43.6 & 30.2 & 20.7 & 46 & 54 & 60 & 65 & 69 \\
\hline No & 84.6 & 66.2 & 54.2 & 41.9 & 71 & 73 & 75 & 76 & 77 \\
\hline \multicolumn{10}{|l|}{ Chemotherapy } \\
\hline Yes & 84.6 & 55.8 & 42.1 & 31.6 & 56 & 62 & 68 & 72 & 74 \\
\hline No & 83.2 & 65.1 & 53.4 & 41.4 & 71 & 73 & 75 & 76 & 77 \\
\hline \multicolumn{10}{|l|}{ Seer stage } \\
\hline local & 90.5 & 75.2 & 63.5 & 50.1 & 76 & 77 & 78 & 79 & 79 \\
\hline regional & 80.6 & 54.2 & 40.9 & 29.9 & 58 & 63 & 68 & 71 & 73 \\
\hline Unknown & 37 & 18.8 & 12.2 & 8.2 & 42 & 49 & 56 & 62 & 67 \\
\hline
\end{tabular}

Abbreviation:

aFor example, in the cohort of aged 15-45 years old, the 4-year survival rate for those who had survived 1 years (CS(4区1)) after diagnosis is $85 \%$, the 8 -year survival rate for those who had survived 5 years (CS(8ه5)) after diagnosis is $93 \%$.

\section{Figures}


Lung Cancer from 1975-2016 years of

SEER database $(\mathrm{n}=1,048,571)$

\section{$\operatorname{SCLC}(\mathrm{n}=75,965)$}

\section{$1975-1999(\mathrm{n}=379,748)$}

Multiple primary tumors

$(\mathrm{n}=152,840)$

Age $<15(n=98)$

Stage M1 $(n=120,298)$

Unknown tumor size $(\mathrm{n}=108,059)$

Unknown or 0 survival month

$$
(\mathrm{n}=20,455)
$$

Surgery $(n=74,439)$

\section{$\mathrm{n}=116,669$}

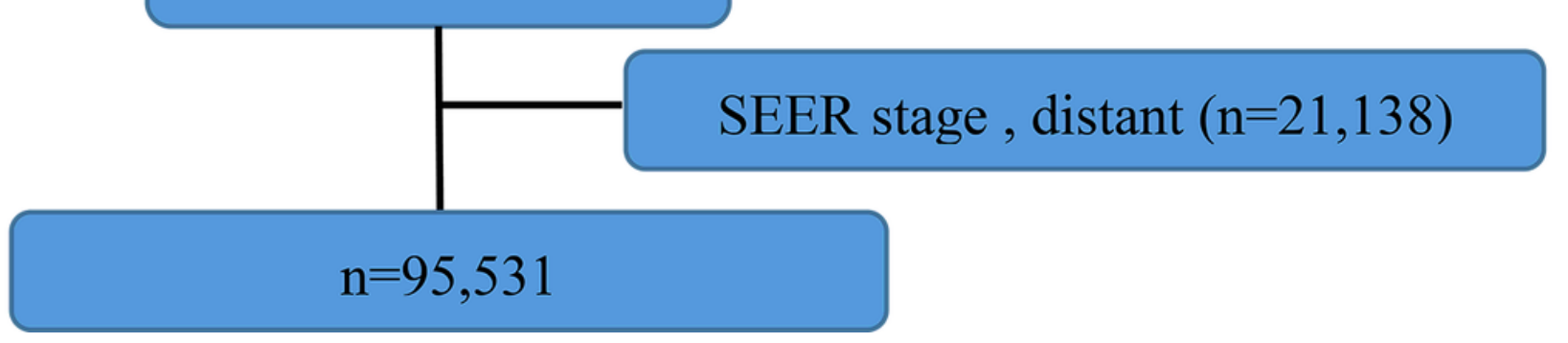

\section{Figure 1}

Flow chart of data inclusion and exclusion. 
A

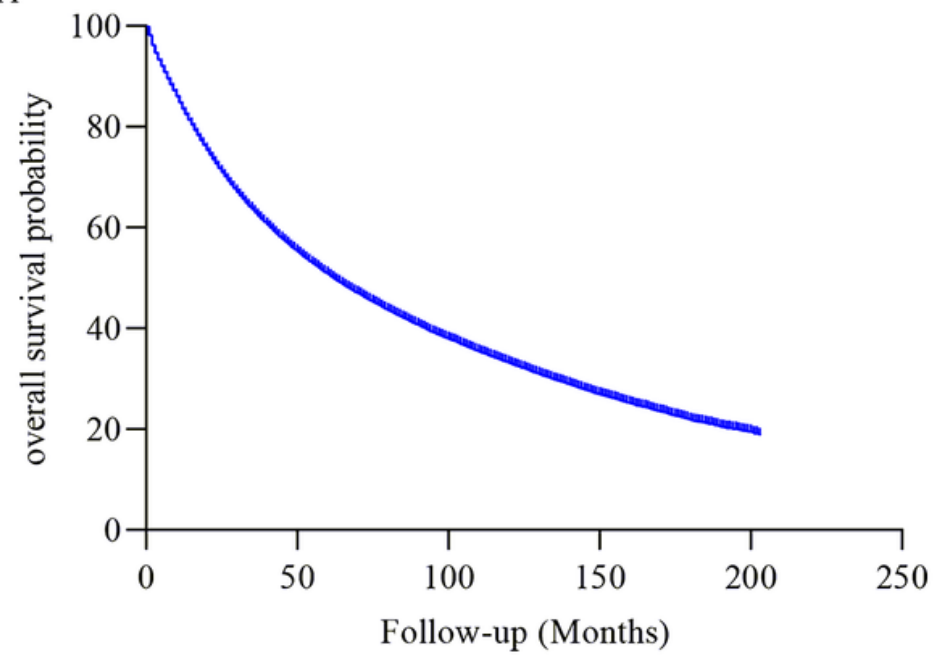

C

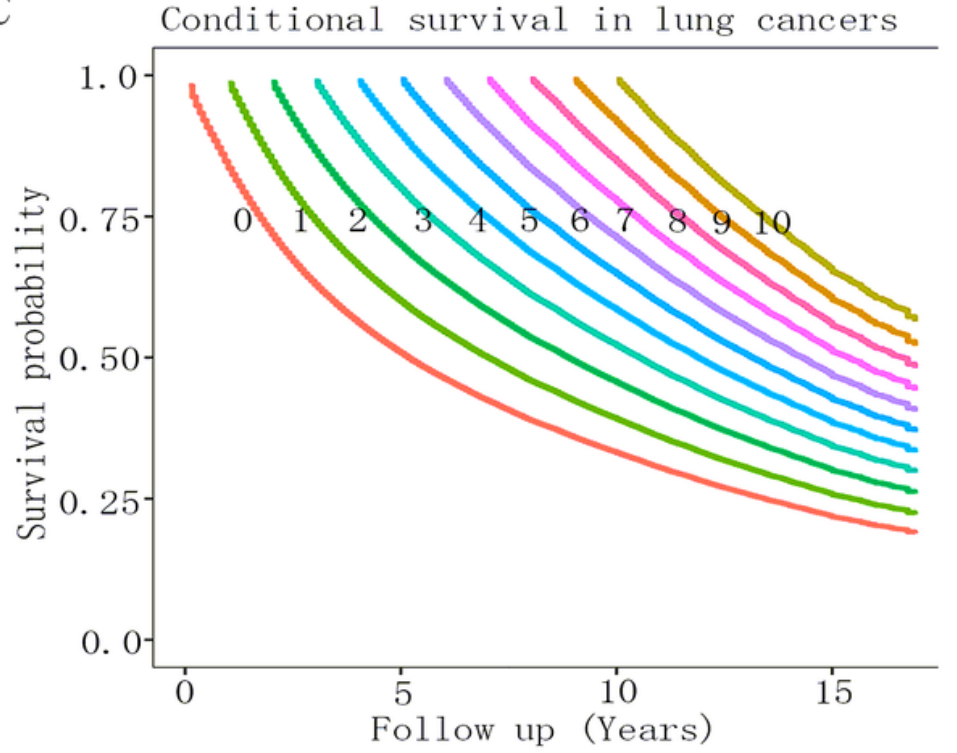

B

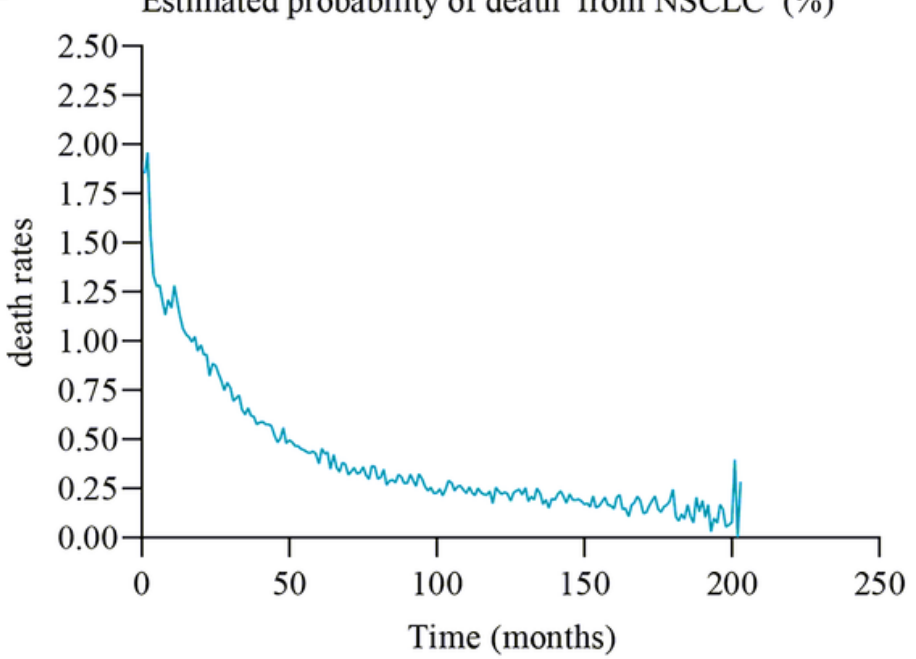

D

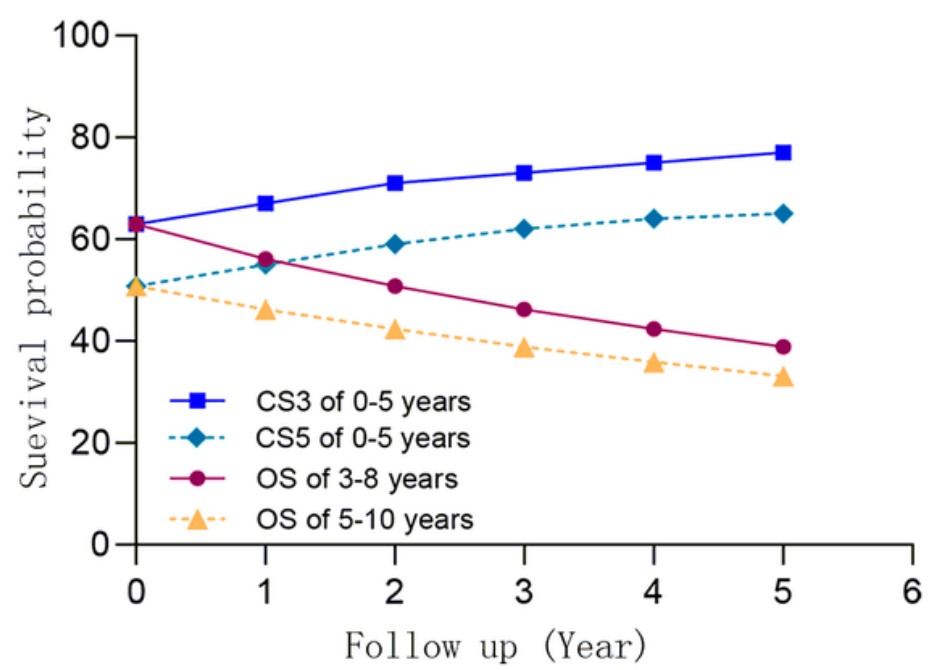

\section{Figure 2}

The overall survival and conditional survival of 99531 patients. Note: The overall survival rate (A), Timedependent mortality of lung cancer (B), Kaplan-Meier graphs for overall survival according to duration of survivorship (C), 3- , 5-year actuarial survival and conditional survival probability based on 0-5 years survival after surgical perform (D). 

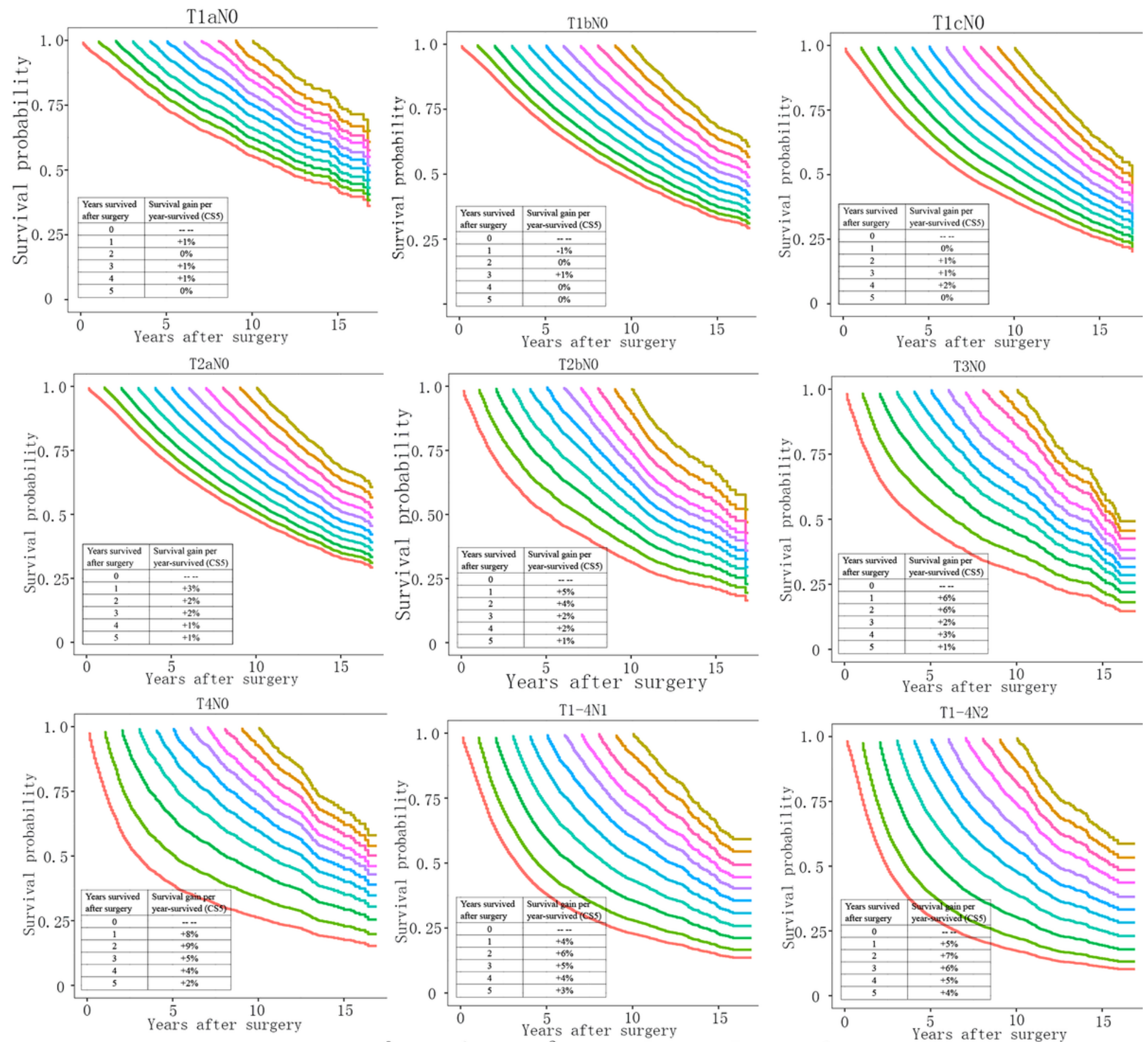

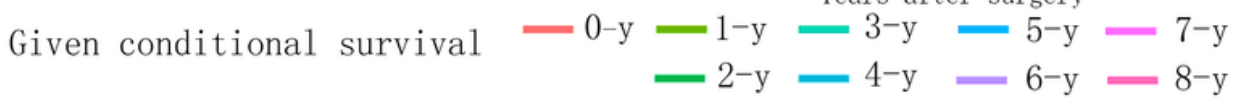

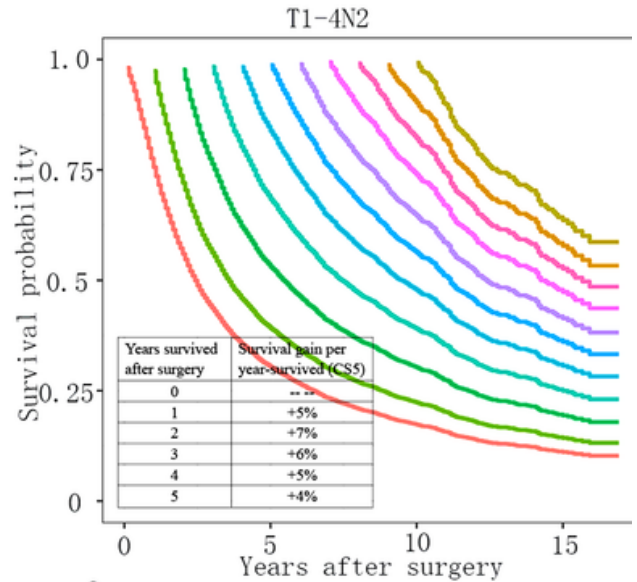

$$
\begin{aligned}
& -9-y \\
& -10-y
\end{aligned}
$$

\section{Figure 3}

Kaplan-Meier method was used to estimate the survival rate in different cohort. Note: (T1aN0, T1bN0, $\mathrm{T} 1 \mathrm{cNO}, \mathrm{T} 2 \mathrm{aNO}, \mathrm{T} 2 \mathrm{bNO} 0, \mathrm{~T} 3 \mathrm{~N} 0, \mathrm{~T} 4 \mathrm{~N} 0, \mathrm{~T} 1-4 \mathrm{~N} 1, \mathrm{~T} 1-4 \mathrm{~N} 2)$ given the survival of 0-10 years after resection of NSCLC. 
A
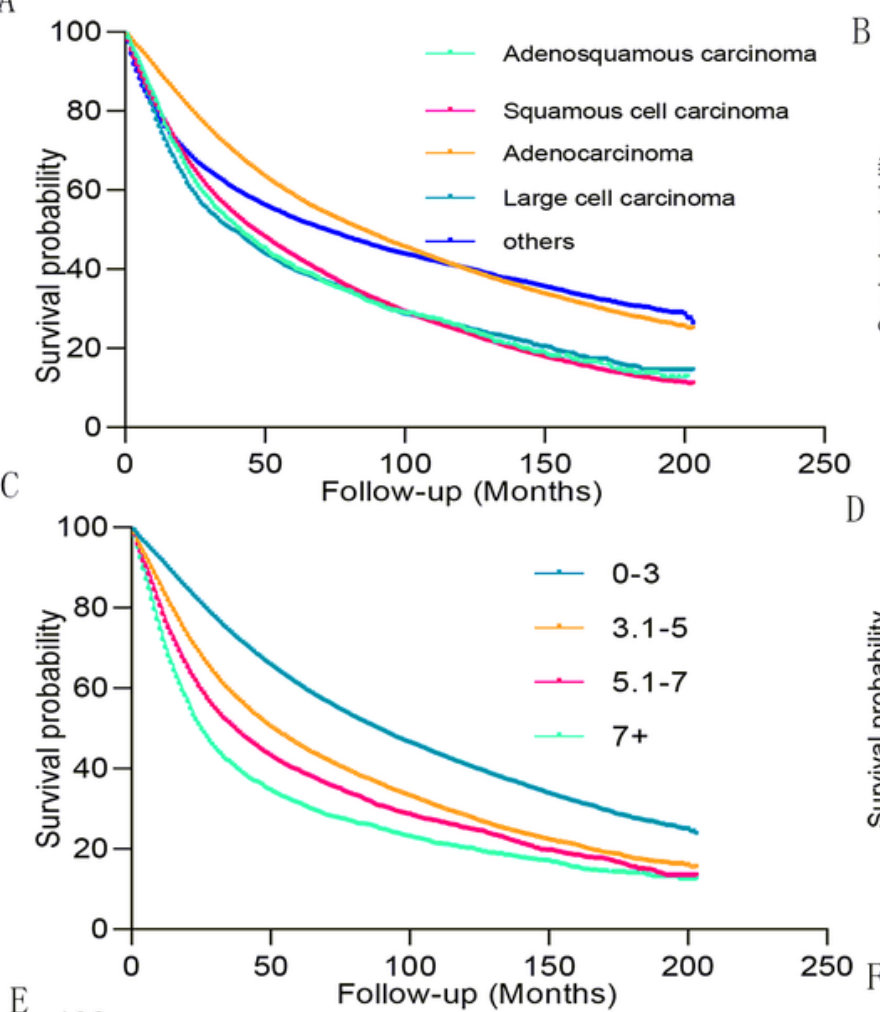

E

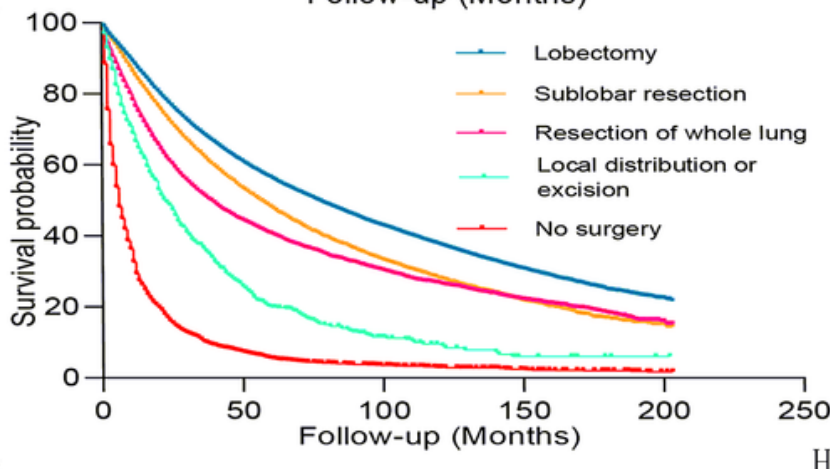

G

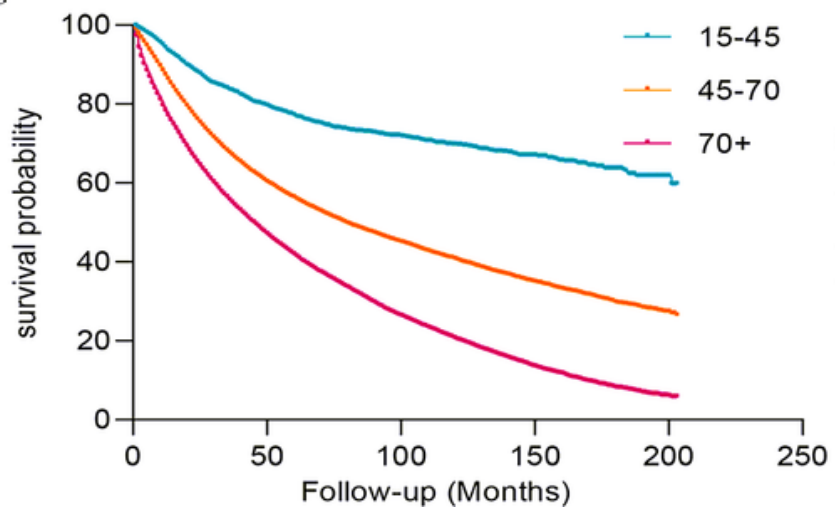

$\mathrm{H}$
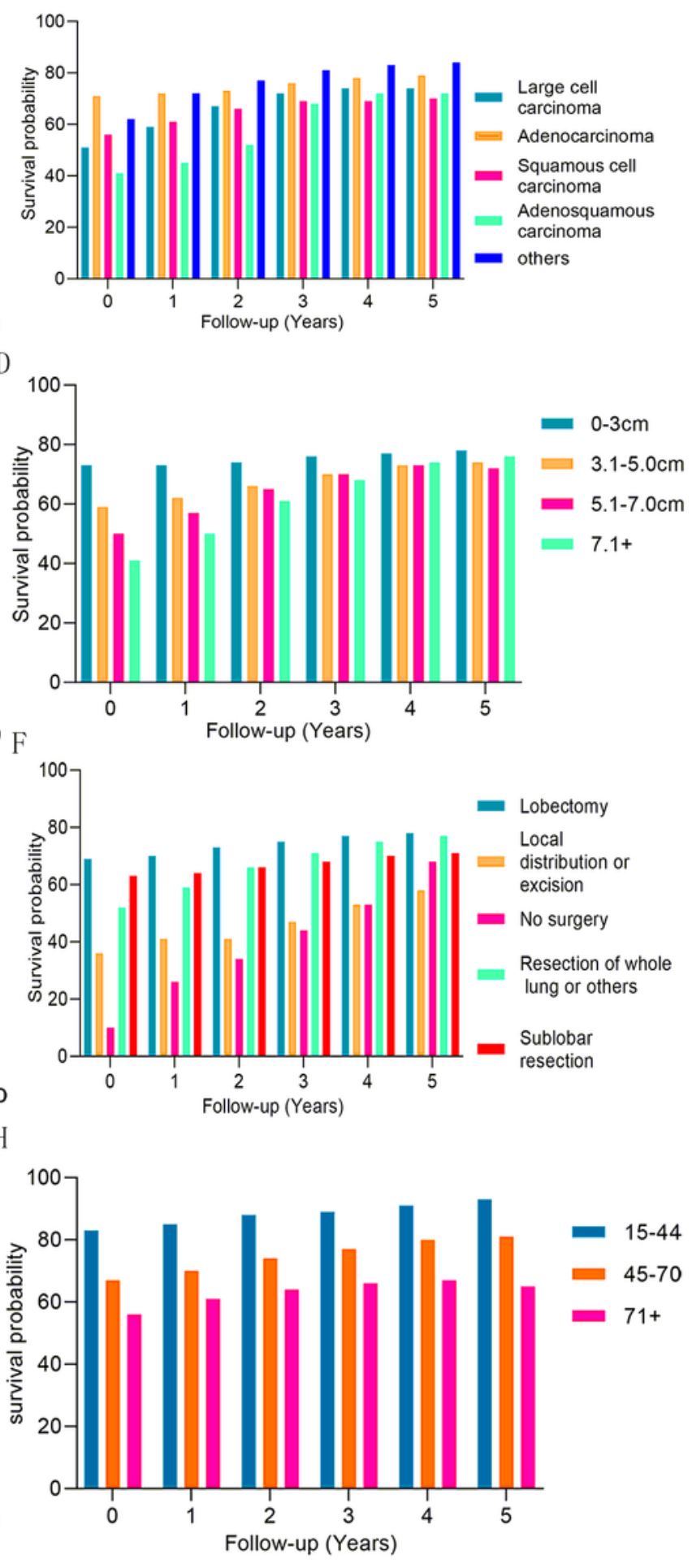

Figure 4

The overall survival and conditional survival based on different variables. Note: The overall survival of histological types (A), tumor size (C), surgical intervention (E) and age (G). 3-year conditional probability of histological types $(B)$, tumor size $(D)$, surgical intervention $(F)$ and age $(H)$. 

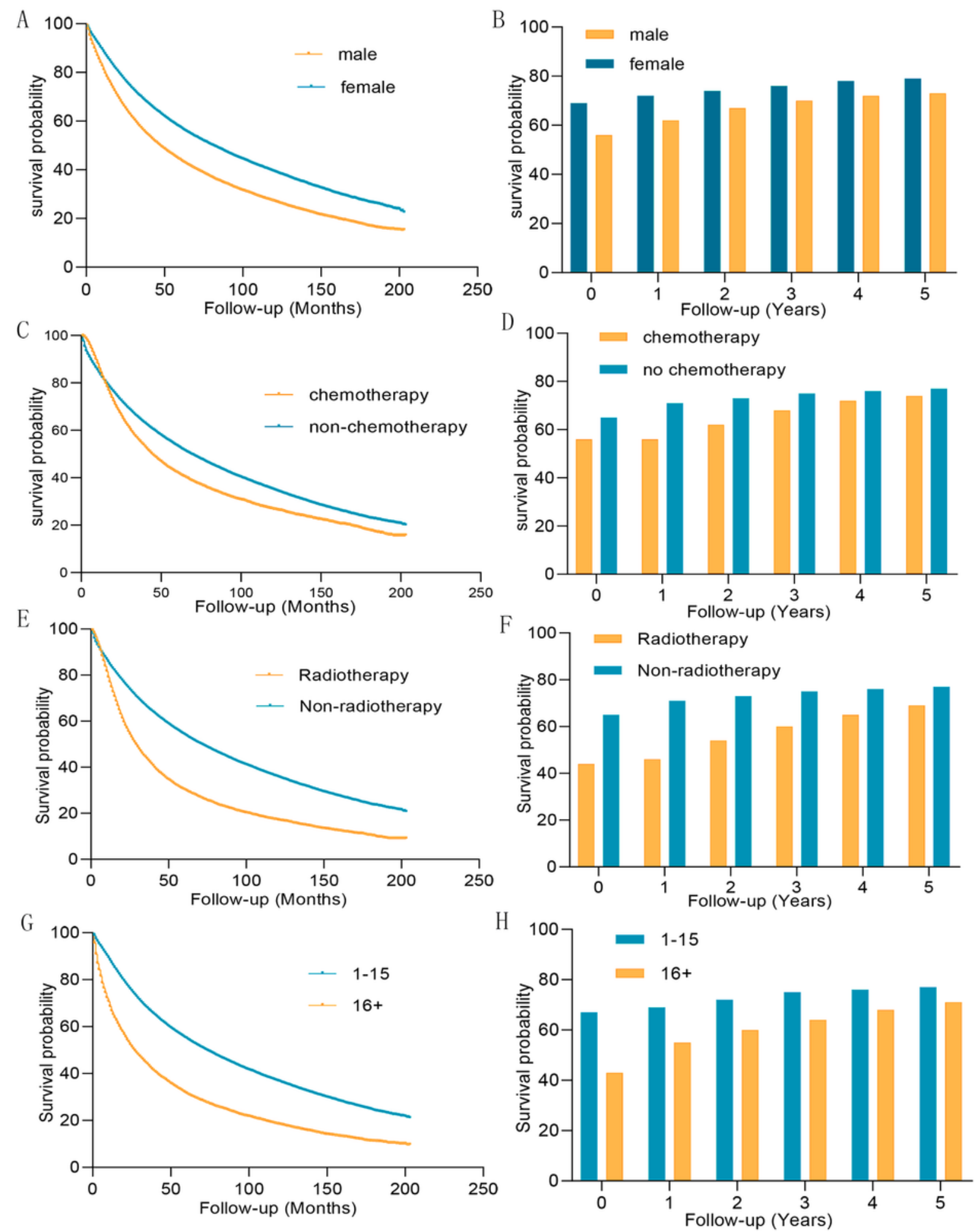

Figure 5

The overall survival and conditional survival based on different histological types. Note: gender (A), chemotherapy (C), radiotherapy (E) and lymph node involvement $(\mathrm{G})$. And 3-year conditional probability in accordance with different survival years after resection based on different stratification by gender $(B)$, chemotherapy (D), radiotherapy $(F)$ and lymph node involvement $(H)$. 


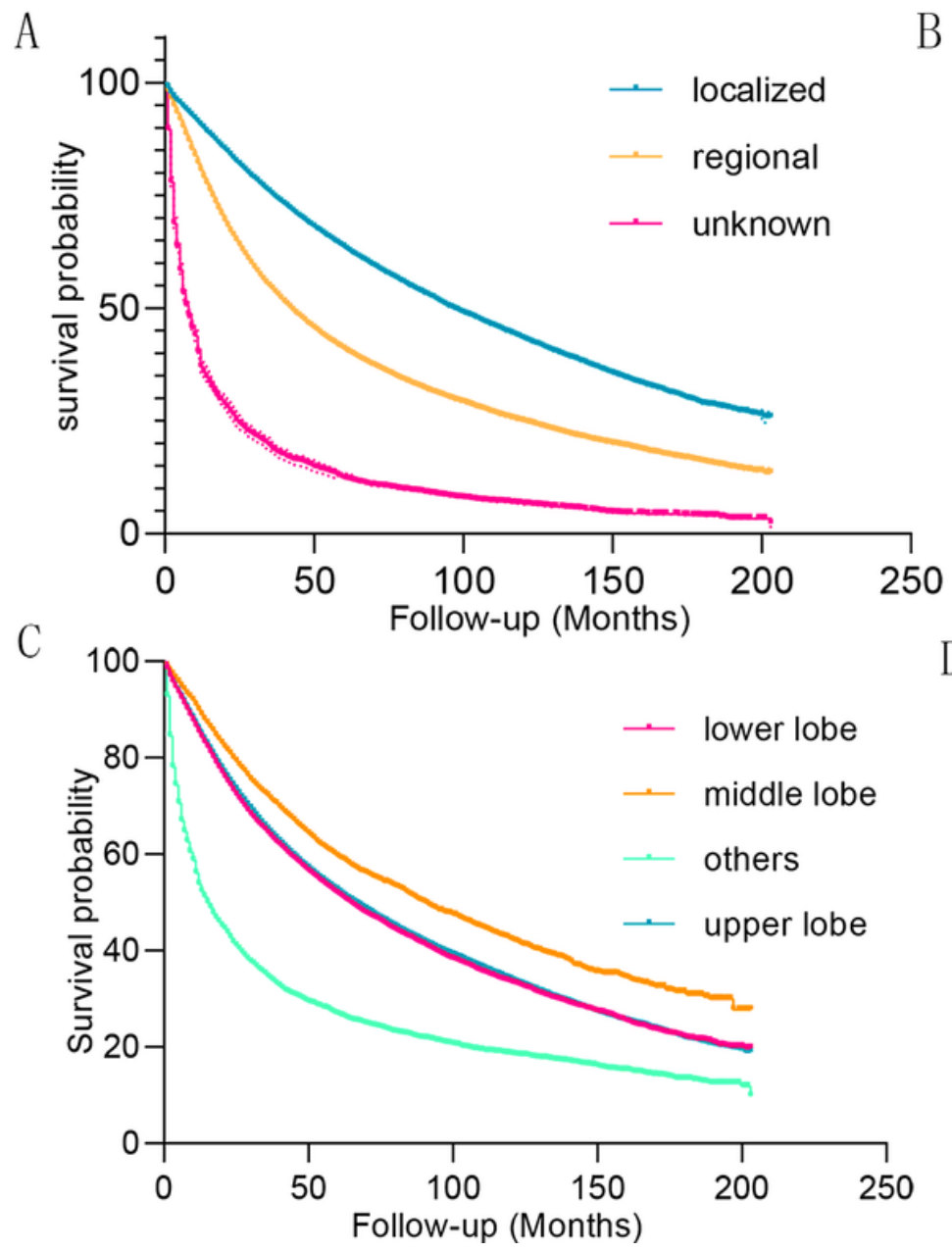

B

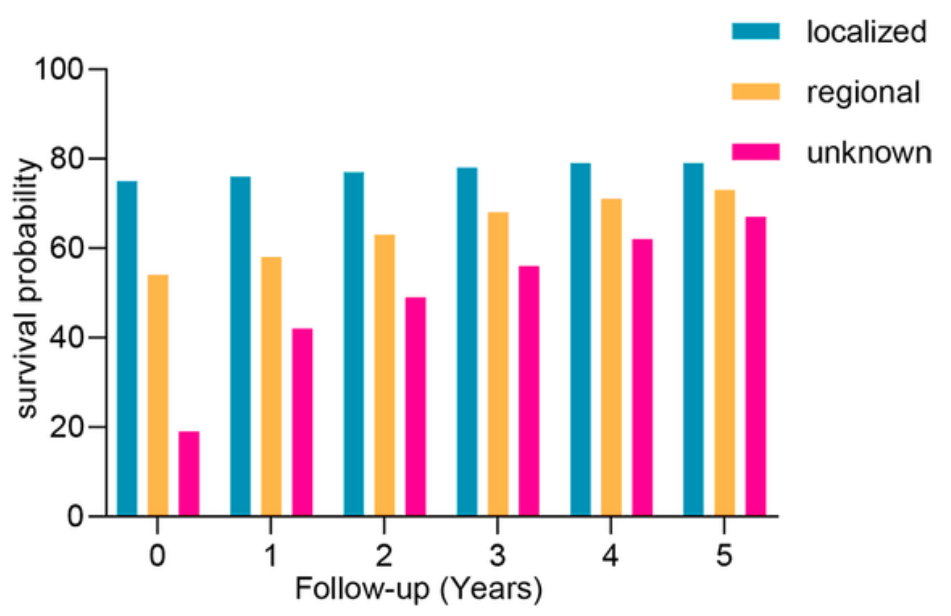

D

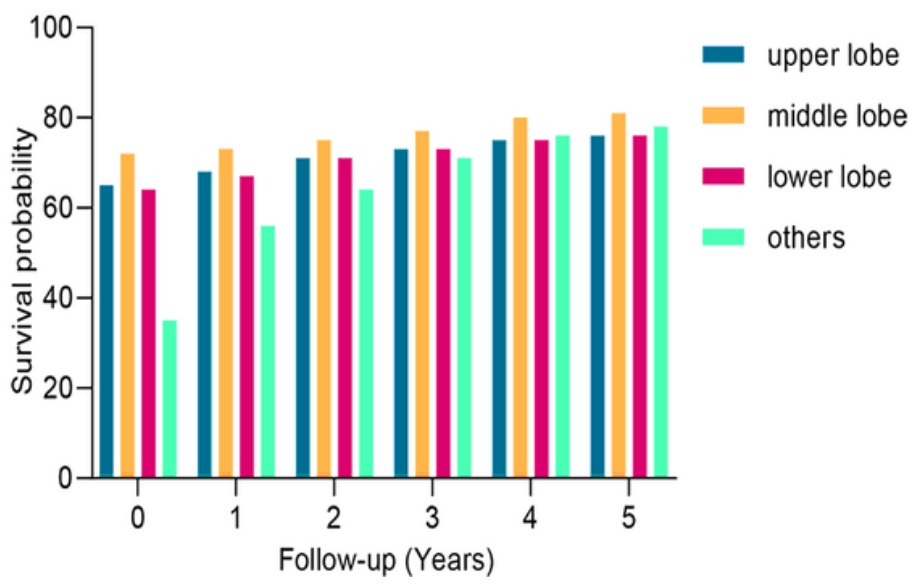

Figure 6

The overall survival and 3-year conditional probability in accordance with different histological types. Note: SEER stage (A-B), Lobectomy site (C-D) 